\title{
PENGARUH PEMBERIAN BERBAGAI KONSENTRASI ETHEPON TERHADAP PERTUMBUHAN DAN HASIL TANAMAN MENTIMUN (Cucumis sativus L.) VARIETAS LOKAL DAN ANTARA
}

\author{
(Effect of Ethepon Concentrations on Growth and Yield of Cucumber (Cucumis sativus L.) var. Local \\ and Antara)
}

NOVITA HERA $^{(1)}$, ZULFADLY SYARIF ${ }^{(2)}$, DAN IRAWATI CHANIAGO ${ }^{(2)}$

(1) Fakultas Pertanian dan Peternakan

Universitas Islam Negeri Sultan Syarif Kasim Riau

JI. H.R. Soebrantas No. 155 KM 15 Simpang Baru Panam Pekanbaru Riau 28293

(2) Fakultas Pertanian Universitas Andalas

Jl. Limau Manis, Padang

Email: novitahera86@yahoo.com HP : 081363346956

\begin{abstract}
The research was conducted from June to August 2008 in Nagari Kacang village, $X$ Koto Singkarak district, Solok Regency, West Sumatera. The objectives of the study were (1) to obtain interaction between several concentrations of ethephon with cucumber varieties, (2) to obtain the best ethepon concentration, (3) and to get the best cucumber varieties that have high production. The experiment employed randomized-completely-block-design (RCBD) with two factors. The first factor was ethepon concentration that consist of five levels 0, 100, 200, 300 and $400 \mathrm{ppm}$. The second was cucumber varieties i.e. Local and Antara. The result showed that 200 ppm ethepon increases number of female flower, number of straight fruit, and weight of the fruit straight. Local variety gave better production than those of Antara. Combination of ethepon and varieties contributed to a significant effect on the speed of first male flowers appearance.
\end{abstract}

Keywords : Cucumber, Ethepon, Growth, Yield

\section{PENDAHULUAN}

Prospek budidaya mentimun makin cerah seiring laju pertambahan penduduk, peningkatan pendidikan, dan peningkatan kesadaran gizi masyarakat. Beberapa negara yang menjadikan sasaran ekspor mentimun Indonesia adalah Malaysia, Singapura, Jepang, Prancis, dan Belanda.

Produksi mentimum Sumatera Barat pada tahun 2006 sebesar 14.852 ton, dan pada tahun 2014 naik menjadi 20.892 ton. Peningkatan produksi mentimun ini belum mampu mencukupi kebutuhan dan memnuhi kriteria yang diinginkan eksportir (BPS, 2015). Dalam hal ini perlu suatu usaha yang ditujukan untuk meningkatkan produktivitas tanaman mentimun.

Varietas mentimun hibrida yang akhirakhir ini banyak dikembangkan adalah varietas Delight Green, Gennie, Green Alpha, Summer Fresh, Pluto, Panda, Venus Antara, dan lain-lain (Samadi, 2002). Pada percobaan ini penulis menggunakan varietas Antara yang mempunyai beberapa kelebihan dibandingkan dengan varietas lain, yaitu mempunyai kelebihan tekstur renyah, tidak pahit, tahan simpan, dan daya adaptasi luas. Benih varietas mentimun Hibrida bisa didapatkan di toko-toko pertanian.

Produksi buah mentimun berkaitan erat dengan perimbangan antara bunga jantan dengan bunga betina. Apabila diperoleh terlalu banyak jumlah bunga jantan, maka dapat diduga bahwa produksi buah akan menurun. Namun sebaliknya, dengan jumlah bunga betina yang relatif banyak, maka produksi akan memperlihatkan peningkatan. Tanaman mentimun yang berumah satu seringkali memiliki bunga jantan yang cukup banyak, hal ini akan mengakibatkan produksi buah mentimun akan menurun. Oleh karena itu perlu suatu upaya untuk dapat merubah ekspresi seksual bunga mentimun yang mengakibatkan terjadinya peningkatan bunga betina.

Salah satu upaya yang sering digunakan untuk meningkatkan pertumbuhan dan produksi tanaman dapat dilakukan dengan memberikan zat pengatur tumbuh tanaman (ZPT). Zat pengatur tumbuh tanaman yang dewasa ini banyak digunakan adalah auksin, giberelin, sitokinin, etilen, dan asam absisik. Masing-masing zat pengatur tumbuh tersebut memberikan respon yang berbeda terhadap pertumbuhan dan perkembangan tanaman tertentu. 
Etilen merupakan salah satu zat pengatur tumbuh yang dapat menyebabkan beberapa respon tanaman seperti epinasti, pengguguran daun, pembengkakan batang, pemasakan buah, penghilangan warna bunga, dan ekspresi seksual. Etilen yang diperdagangkan sekarang adalah ethrel 40 PGR dengan bahan aktif ethepon atau 2 kloroetil posponat $\left(\mathrm{CL}-\mathrm{CH}_{2}-\mathrm{CH}_{2}-\mathrm{PO}_{3} \mathrm{H}_{2}\right)$ yang dalam air terurai menjadi etilen, $\mathrm{Cl}^{-}$dan $\mathrm{H}_{2} \mathrm{PO}_{4}^{-1}$ (Wattimena, 1987). Seperti dijelaskan juga bahwa etilen mampu mengubah ekspresi seksual tanaman. Etilen yang diberikan dalam bentuk ethephon dapat meningkatkan jumlah bunga betina (Thomas (1982) cit. Irawati 1990).

Keberhasilan penggunaan ethepon sangat dipengaruhi oleh konsentrasi, cara penggunaan, varietas dan macam bibit yang ditanam. Oleh karena itu perlu bimbingan dan penyuluhan dalam menggunakan ethephon ini (Haryati, 2003). Wattimena (1987) menyatakan bahwa pemberian etilen dapat merangsang pembungaan dan memperbaiki mutu buah pada tanaman pangan. Irawati (1990), menyatakan bahwa pemberian ethepon dengan konsentrasi $200 \mathrm{ppm}$ terhadap tanaman mentimun belum memperlihatkan pengaruh yang nyata dan hasil yang didapatkan belum optimal.

Tujuan dari penelitian ini adalah (1) Untuk melihat interaksi yang terbaik antara pemberian beberapa konsentrasi ethepon dengan varietas tanaman mentimun, (2) untuk mendapatkan konsentrasi ethepon yang terbaik, (3) dan untuk mengetahui varietas mentimun yang terbaik agar dapat tumbuh dan memberikan produksi yang lebih baik

\section{BAHAN DAN METODE}

Penelitian ini dilakukan di Jorong Kucai Nagari Kacang Kecamatan $X$ Koto Singkarak Kabupaten Solok dengan ketinggian tempat $450 \mathrm{~m}$ dpl. Bahan yang digunakan dalam penelitian ini adalah benih mentimun varietas Antara dan varietas Lokal, Etilen (dalam bentuk Ethepon), air, pupuk kandang sapi, pupuk buatan (Urea, SP-36, KCL), bahan perekat "MANTAB" (Surfactant).

Penelitian ini menggunakan

Rancangan Acak Kelompok (RAK) secara Faktorial $5 \times 2$ dengan 3 kelompok. Faktor pertama adalah : konsentrasi ethepon yaitu : 0 ppm, 100 ppm, 200 ppm, 300 ppm dan 400 ppm. Faktor kedua adalah : varietas mentimun yaitu : Varietas Lokal dan Varietas Antara. Peubah yang diamati panjang tanaman, jumlah cabang, jumlah bunga jantan, jumlah bunga betina, jumlah buah lurus, jumlah buah tidak lurus, bobot buah lurus, dan bobot buah tidak lurus/ bengkok. Analisis statistik dilakukan dengan uji $\mathrm{F}$ pada taraf nyata $5 \%$. Jika $\mathrm{F}$ hitung lebih besar dari $\mathrm{F}$ tabel $5 \%$, maka dilanjutkan dengan Duncan's New Multiple range Test (DNMRT).

\section{HASIL DAN PEMBAHASAN}

\section{Panjang Tanaman}

Pemberian beberapa konsentrasi ethepon dengan varietas menunjukkan tidak ada efek interaksi terhadap panjang tanaman mentimun. Faktor tunggal pemberian beberapa konsentrasi ethepon maupun perbedaan varietas yang dicobakan berpengaruh terhadap panjang tanaman (Tabel 1.)

Tabel 1. Panjang Tanaman (cm) dan Jumlah Mentimun pada Perlakuan Beberapa Konsentrasi Ethephon dan Varietas yang Berbeda

\begin{tabular}{ccc}
\hline Perlakuan & Parameter \\
\hline Konsentrasi Ethepon $(\mathrm{ppm})$ & Panjang Tanaman & Jumlah Cabang \\
\hline 0 & $124,45^{\mathrm{a}}$ & 1,70 \\
100 & $110,20^{\mathrm{a}}$ & 1,50 \\
200 & $107,75^{\mathrm{a}}$ & 1,85 \\
300 & $89,05^{\mathrm{b}}$ & 1,80 \\
400 & $87,60^{\mathrm{c}}$ & 1,65 \\
\hline Varietas Mentimun & & 1,52 \\
Lokal & $81,48^{\mathrm{a}}$ & 1,94 \\
\hline Antara & $126,10^{\mathrm{b}}$ &
\end{tabular}

Panjang tanaman mentimun yang terpendek adalah pemberian ethepon dengan konsentrasi 400 ppm yaitu $87,6 \mathrm{~cm}$, lalu diikuti oleh pemberian ethepon dengan konsentrasi $300 \mathrm{ppm}$ yaitu $89,05 \mathrm{~cm}$. Sedangkan pemberian ethepon dengan konsentrasi 0 ,
100, dan 200 ppm memberikan pengaruh yang sama terhadap peningkatan panjang batang tanaman mentimun.

Fenomena ini disebabkan tercapainya keseimbangan antara auksin dengan etilen endogen sehingga pertumbuhan panjang 
tanaman lebih didominasi oleh auksin. Menurut Menurut Rahmawaty (2009) cit Sidauruk et al. (2013), semakin tinggi konsentrasi ethepon maka panjang tanaman akan semakin pendek. Hal ini disebabkan ethepon yang dihasilkan akan menghambat pemanjangan sel batang karena konsentrasi yang tinggi menghambat kerja auksin yang berguna untuk stimulasi pertembuhan sel. Peningkatan konsentrasi ethepon yang diberikan menyebabkan semakin pendeknya tanaman mentimun.

Pemberian ethepon menekan pertumbuhan atau pertambahan panjang ruas batang tanaman mentimun. Hal ini sesuai dengan pendapat Harryjanto (1987), bahwa perlakuan ethrel (ethepon) menyebabkan terhambatnya perpanjangan ruas batang tanaman mentimun sehingga tanaman menjadi pendek, karena auksin menyebar secara lateral ke luar dari phloem sehingga setelah pemberian etilen (dalam bentuk ethrel/ethepon) pada suatu tempat kadar auksinnya tidak sama. Dengan adanya etilen akan dapat menyebabkan auksin tidak aktif, karena umumnya etilen memiliki sifat yang berlawanan dengan auksin (Wattimena, 1987).

Penanaman mentimun varietas Antara mempunyai panjang tanaman yang lebih panjang yaitu 126,14 cm dibandingkan varietas Lokal yaitu $81,48 \mathrm{~cm}$. Perbedaan panjang tanaman pada varietas tanaman mentimun dikarenakan adanya perbedaan varietas yang diuji dan masing-masing varietas memiliki sifat genetik yang berbeda. Perbedaan sifat genetik antara beberapa varietas menyebabkan tanaman memberikan respon yang berbeda terhadap lingkungannya.

\section{Jumlah Cabang}

Pemberian beberapa konsentrasi ethepon dan varietas mentimun memberikan pengaruh yang sama terhadap jumlah cabang. Hal ini menggambarkan bahwa pemberian beberapa konsentrasi ethepon dan varietas mentimun tidak menentukan terhadap jumlah cabang yang terbentuk. Jumlah cabang didominasi oleh pengaruh lingkungan dan sifat tanaman itu sendiri. Di samping itu, faktor lain yang juga berpengaruh untuk menentukkan jumlah cabang adalah hara. Menurut Sumarno, (1986 dan Rinsema, )1986) hara yang paling banyak berpengaruh untuk pembentukkan cabang dan ranting adalah unsur $\mathrm{N}$.

\section{Jumlah bunga jantan (per buah)}

Pemberian beberapa konsentrasi ethepon menentukkan jumlah bunga jantan, sedangkan penggunaan varietas tanaman mentimun tidak memberikan pengaruh nyata terhadap jumlah bunga jantan terbentuk (Tabel 2.)

Tabel 2. Jumlah Bunga Jantan(Buah), Jumlah Bunga Betina (Buah), Jumlah Buah Lurus (Buah), Jumlah Buah Tidak Lurus (Buah), Bobot Buah Lurus (g) Bobot Buah Tidak Lurus/Tanaman (g) Tanaman Mentimun pada Perlakuan Beberapa Konsentrasi Ethephon dan Varietas yang Berbeda

\begin{tabular}{|c|c|c|c|c|c|c|}
\hline \multirow[b]{2}{*}{ Perlakuan } & \multicolumn{6}{|c|}{ Parameter } \\
\hline & \multirow{2}{*}{$\begin{array}{c}\text { Jumlah } \\
\text { Bunga } \\
\text { Jantan }\end{array}$} & \multirow{2}{*}{$\begin{array}{l}\text { Jumlah } \\
\text { Bunga } \\
\text { Betina }\end{array}$} & \multirow{2}{*}{$\begin{array}{l}\text { Jumlah } \\
\text { Buah } \\
\text { Lurus }\end{array}$} & \multirow{2}{*}{$\begin{array}{l}\text { Jumlah Buah tidak } \\
\text { lurus (Bengkok) }\end{array}$} & \multirow{2}{*}{$\begin{array}{l}\text { Bobot Buah } \\
\text { Lurus }(\mathrm{g})\end{array}$} & \multirow[t]{2}{*}{$\begin{array}{c}\text { Buah Buah } \\
\text { Tidak Lurus } \\
\text { (Bengkok) (g) }\end{array}$} \\
\hline $\begin{array}{l}\text { Konsentrasi } \\
\text { Ethepon } \\
(\mathrm{ppm})\end{array}$ & & & & & & \\
\hline 0 & $10,30^{\mathrm{a}}$ & 10,25 & 4,2 & $1,55^{\mathrm{a}}$ & 1209,95 & 605 \\
\hline 100 & $8,08^{b}$ & 7,85 & 3,95 & $1,60^{\mathrm{a}}$ & 933,3 & 657,5 \\
\hline 200 & $6,60^{b}$ & 12,05 & 4,75 & $2,70^{\mathrm{b}}$ & 1263,3 & 1020 \\
\hline 300 & $7,45^{b}$ & 1,85 & 3,85 & $1,85^{\mathrm{a}}$ & 838,5 & 622,5 \\
\hline 400 & $2,85^{\mathrm{c}}$ & 1,80 & 4,05 & $1,80^{\mathrm{a}}$ & 1029,2 & 520 \\
\hline \multicolumn{7}{|l|}{$\begin{array}{l}\text { Varietas } \\
\text { Mentimun }\end{array}$} \\
\hline Lokal & 6,93 & 10,24 & $4,82^{a}$ & $3,12^{\mathrm{a}}$ & $858,98^{a}$ & $1067^{a}$ \\
\hline Antara & 7,18 & 8,50 & $3,50^{b}$ & $0,68^{\mathrm{b}}$ & $1250,72^{b}$ & $383^{b}$ \\
\hline
\end{tabular}

Keterangan : Angka-angka pada kolom yang diikuti huruf tidak berbeda berdasarkan uji $\mathrm{F}$ pada taraf nyata $5 \%$

Jumlah bunga jantan bergantung pada peningkatan konsentrasi ethepon yang diberikan. Jumlah bunga jantan yang paling sedikit didapatkan pada perlakuan ethepon dengan konsentrasi 400 ppm yaitu 2,85 buah diikuti dengan konsentrasi 100, 200, dan 300 ppm yaitu masing-masing sebanyak 8,08, 6,6, dan 7,45 buah. Jumlah bunga jantan terbanyak pada pemberian ethepon $0 \mathrm{ppm}$ yaitu 10,3 yang berbeda nyata dengan konsentrasi lainnya. Pemberian ethepon dengan konsentrasi 100, 200, dan 300 ppm 
memberikan pengaruh yang tidak berbeda nyata terhadap bunga betina yang terbentuk. Makin meningkatnya kepekatan ethepon menyebabkan semakin berkurangnya jumlah bunga jantan. Etilen dapat menstimulir bunga betina tanaman mentimun (Robinson et al. (1969) cit. Irawati, (1990)). Pada tanaman mentimun, masing-masing bunga memiliki kedua jenis kelamin yang rudimenter, dan uniseksualitas merupakan hasil penekanan salah satu jenis kelamin terhadap jenis kelamin lainnya. Etilen mampu menekan pembentukan bunga jantan. (Heslop 1963 cit Irawati (1990)

\section{Jumlah bunga betina (per buah)}

Beberapa konsentrasi ethepon dan varietas mentimun memberikan pengaruh yang tidak berbeda terhadap jumlah bunga betina yang terbentuk (Tabel 2). Hal ini diduga disebabkan karena penyerapan ethepon yang diberikan dalam bentuk cair belum optimal diserap oleh tanaman mentimun.

Hasil penelitian ini berbeda dengan pendapat Muhajir et al. (1990), bahwa pemberian ethepon dapat merangsang pembungaan dan memperbaiki mutu, dan Kusumaningsih (1989) juga menyatakan bahwa pemberian ethepon menyebabkan meningkatnya jumlah bunga yang terbentuk pada tanaman mentimun, karena meningkatnya kandungan etilen dalam tanaman sehingga tanaman dirangsang untuk membentuk bunga.

\section{Jumlah buah lurus (per buah)}

Jumlah buah lurus tanaman mentimun tidak bergantung pada pemberian beberapa konsentrasi ethepon. Perbedaan jumlah buah lurus terlihat diantara dua varietas mentimun yang ditanam (Tabel 2).

Jumlah buah lurus pada varietas Lokal lebih banyak daripada varietas Antara. Jumlah buah yang dihasilkan erat kaitannya dengan jumlah bunga betina yang dihasilkan. Bila bunga betina lebih banyak dihasilkan, kemungkinan buah yang terbentuk juga banyak. Pada umumnya semakin banyak bunga yang terbentuk maka banyak pula jumlah bunga yang akan mengalami penyerbukan dan pembuahan (Darjanto dan Satifah, 1982).

Bunga betina (bakal buah) yang dihasilkan tidak semuanya menjadi buah yang dapat dipanen masak pada percobaan. Ini dapat dilihat dari jumlah bunga betina yang terbentuk tidak sama dengan jumlah bunga yang dihasilkan. Hal ini diduga karena keberhasilan pembentukan buah ini tergantung pada proses penyerbukan dan kondisi lingkungan. Gagalnya penyerbukan dapat menyebabkan bunga dan bakal buah gugur atau mati. Serbuk sari yang melakukan penyerbukan rusak atau mandul atau bisa juga kepala putiknya tidak sehat. Pada kenyataannya bunga betina yang mampu berkembang menjadi buah kurang dari $60 \%$, sisanya gugur sebelum menjadi buah (Rukmana, 1994).

\section{Jumlah buah tidak lurus/bengkok (per buah)}

Beberapa konsentrasi ethepon maupun perbedaan varietas mentimun yang digunakan memberikan pengaruh nyata terhadap jumlah buah tidak lurus. Pada Tabel 2 dapat dilihat bahwa ethepon dengan konsentrasi 200 ppm menunjukkan jumlah buah tidak lurus (bengkok) yang paling tinggi yaitu 2,70 buah dibandingkan dengan ethepon $0,100,300$, dan 400 ppm. Sedangkan ethepon 0, 100, 300, dan 400 ppm memberikan pengaruh yang sama terhadap jumlah buah tidak lurus/bengkok yaitu berturutturut 1,$55 ; 1,60 ; 1,85$, dan 1,80 buah.

Penggunaan mentimun varietas Antara memperlihatkan pengaruh yang lebih baik terhadap jumlah buah tidak lurus yaitu 0,68 buah dibandingkan varietas Lokal yaitu 3,12 buah. Adanya buah tidak lurus/bengkok pada tanaman mentimun ini diduga karena terhambatnya pertumbuhan buah mentimun. Buah mentimun yang pertumbuhannya belum maksimal jika bersentuhan langsung dengan tanah akan menghambat pertumbuhan buah sehingga buah tersebut akan mengalami pembengkokkan.

Perbedaan jumlah buah tidak lurus/bengkok pada beberapa varietas tanaman mentimun dikarenakan adanya perbedaan varietas yang diuji dan masingmasing varietas memiliki sifat genetik yang berbeda. Perbedaan sifat genetik antara beberapa varietas menyebabkan tanaman memberikan respon yang berbeda terhadap lingkungannya.

\section{Bobot buah lurus (setiap tanaman sampel)}

Pemberian beberapa konsentrasi ethepon tidak memberikan pengaruh terhadap jumlah buah lurus. Sedangkan penggunaan beberapa varietas mentimun berpengaruh terhadap bobot buah lurus (Tabel 2).

Bobot buah lurus varietas Antara secara nyata lebih banyak yaitu 1250,72 g bila dibandingkan dengan varietas Lokal yaitu 858,98 g.. Perbedaan bobot buah lurus pada varietas tanaman mentimun dikarenakan adanya perbedaan varietas yang diuji dan masing-masing varietas memiliki sifat genetik 
yang berbeda diantaranya. Perbedaan sifat genetik antara varietas menyebabkan tanaman memberikan respon yang berbeda terhadap lingkungannya.

Interaksi genetik dan lingkungan juga menentukan hasil suatu varietas. Bila beberapa varietas yang berbeda ditanam pada lingkungan yang sama akan memberikan karakter genetik yang berbeda. Sudah menjadi pengetahuan umum bila beberapa varietas di tanam pada lingkungan yang sama akan memberikan karakter genetik yang berbeda, begitu juga ukuran besar buah bergantung dari varietasnya, semakin besar buah maka semakin besar pula bobot buah.

\section{Bobot buah tidak lurus/bengkok (setiap tanaman sampel)}

Faktor tunggal pemberian beberapa konsentrasi ethepon memberikan pengaruh yang tidak nyata terhadap bobot buah tidak lurus/bengkok, sedangkan penggunaan varietas tanaman mentimun memberikan pengaruh terhadap bobot buah tidak lurus/bengkok (Tabel 2).

Bobot buah tidak lurus/bengkok varietas Antara ternyata lebih sedikit yaitu 383 g dari varietas Lokal yaitu 1067 g. Perbedaan bobot buah tidak lurus pada beberapa varietas tanaman mentimun dikarenakan adanya perbedaan varietas yang diuji dan masingmasing varietas memiliki sifat genetik yang berbeda diantaranya. Perbedaan sifat genetik antara beberapa varietas menyebabkan tanaman memberikan respon yang berbeda terhadap lingkungannya.

\section{KESIMPULAN DAN SARAN Kesimpulan}

Tidak terdapat interaksi antara konsentrasi ethepon dengan varietas tanaman mentimun. Pada konsentrasi 200 ppm ethepon berpengaruh lebih baik pada jumlah bunga betina, jumlah buah lurus, dan bobot buah lurus. Penggunaan varietas Lokal dan varietas Antara secara tunggal berpengaruh terhadap panjang tanaman, saat muncul bunga betina pertama, jumlah buah lurus, jumlah buah bengkok, bobot buah lurus, dan bobot buah bengkok. Varietas mentimun yang menunjukkan produksi lebih baik adalah mentimun varietas Lokal.

\section{Saran}

untuk melakukan penelitian yang serupa dengan konsentrasi ethepon yang sama yaitu 0 , 100, 200, 300, dan 400 ppm dengan varietas dan daerah berbeda, sehingga diketahui varietas dan daerah lain yang lebih baik untuk pertumbuhan dan produksi tanaman mentimun.

\section{DAFTAR PUSTAKA}

[BPS] Badan Pusat Statistik. 2015. Sumatera Barat Dalam Angka 2015. Sumatera Barat.

Darjanto dan Satifah. 1982. Biologi Bunga dan Teknik Penyerbukan Silang Buatan. Gramedia. Jakarta.142 hal .

Harryjanto. 1987. Pengaruh Ethrel dan NAA terhadap Nilai Nisbah Kelamin dan Hasil Panen Tanaman Mentimun (Cucumis sativus L.) Laporan karya ilmiah. Jurusan Budidaya Pertanian IPB.Bogor. 40 hal.

Haryati. 2003. Peranan Ethepon terhadap Pertumbuhan Generatif Tanaman Nenas (Ananas comosus L.). Skripsi. Fakultas Pertanian Universitas Sumatera Utara.

Irawati. 1990. Pengaruh Pemberian Ethepon terhadap Pertumbuhan dan Produksi Tanaman Mentimun (Cucumis sativus L.). Laporan penelitian Proyek SPP/DPP Universitas Andalas Padang. 24 hal.

Kusumaningsih, T. 1989. Pengaruh Pemberian Ethrel 40 PGR dan NAA terhadap Ekspresi Kelamin Bunga dan Hasil Panen Tanaman Mentimun (Cucumis sativus L.). Tesis. Jurusan Budidaya Fakultas Pertanian IPB. Bogor.51 hal.

Muhadjir, F. Darmadjati dan F. Ratna. 1990. Peranan Pupuk Daun dan Zat Pengatur Tumbuh Pada Tanaman Pangan. Buletin Agronomi. I (191): halaman??? Jurusan Budidaya Pertanian Fakultas Pertanian IPB. Bogor. Hal 82-96.

Rinsema, W. T. 1986. Pupuk dan Cara Pemupukan. Bathara Karya Aksara. Jakarta. 319 hal.

Rukmana, R. 1994. Budidaya Mentimun. Kanisius. Yogyakarta. 68 hal.

Samadi, B.2002. Teknik Budidaya Mentimun Hibrida. Kanisius. Yogyakarta. 75 hal.

Sidauruk C.O., J.Ginting, dan J. Napitupulu. 2013. Pengaruh Konsentrasi dan Frekuensi Aplikasi Etephon terhadap Pertumbuhan dan Produksi Tanaman Mentimun (Cucumis sativus, L.). Jurnal Online Agroteknologi. 2 (1): 54-63.

Sumarno. 1986. Teknik Budidaya tanaman mentimun. Sinar Baru. Bandung. 79 hal.

Wattimena, G.A. 1987. Zat Pengatur Tumbuh Tanaman. Pusat Antar Universitas IPB Bogor bekerja sama dengan lembaga sumber daya informasi IPB. Bogor. 145 hal. 
Pengaruh Pemberian Berbagai Konsentrasi Ethepon Terhadap Pertumbuhan (Novita Hera, dkk) 